\title{
Anti-inflammatory potential of the aqueous extract of Cyamopsis tetragonoloba against the MSU-induced arthritis in female Wistar albino rats
}

\author{
Jerine Peter Simon, Ram Kumar Katturaja, Arunraj Namachivayan, Sangeetha Nithyanandham, Manisha \\ Parthasarathy, Sabina Evan Prince* \\ School of Biosciences and Technology, VIT, Vellore-632014, India
}

Received 28th February 2020 / Accepted 2nd June 2020

\begin{abstract}
Objective: Gout is an acute inflammation with joint swelling and pain. Uric acid plays a major role in causing gouty arthritis. Crystal shaped uric acid was found in the joint fluid at the severe condition. Guar gum is an herbal product with numerous medical benefits and its botanical name is Cyamopsis tetragonoloba. This study aims to find the protective activity of Cyamopsis tetragonoloba against the MSUinduced gouty arthritis in female Wistar albino rats. Methods: The parameters like weight assessment, paw volume, biochemical parameters (urea, uric acid and creatinine), antioxidant activities and histopathological of paw have been analyzed. The animals have been divided into 5 groups as follows 1 ) normal control, 2) Monosodium Urate Crystal (MSU)-induced on $1^{\text {st }}$ day, 3) MSU-induced and treated with $500 \mathrm{mg}$ of Cyamopsis tetragonoloba, 4) MSU-induced and treated with $1000 \mathrm{mg}$ of Cyamopsis tetragonoloba and 5) MSU-induced and treated with indomethacin. Results: Aqueous extract of Cyamopsis tetragonoloba has shown reduced paw volume, renal markers, lipid peroxidation and acid phosphatase, whereas it raised anti-oxidants levels and diminished the inflammation in rats paw bone. Conclusion: The aqueous seed extract of Cyamopsis tetragonoloba has shown good benefits against MSU-induced gouty arthritis. The molecular studies have to be studied to known this mechanism in treating the inflammation.
\end{abstract}

Keywords: Cyamopsis tetragonoloba, gout, antioxidant, lipid peroxidation, inflammation, guar gum

\section{INTRODUCTION}

The term gout was derived from the Latin word gutta meaning drops. Gout was identified and reported in Hippocratic Oath over many years back, the reports revealed some of the ancient figures such as Charles $\mathrm{V}$, Benjamin Franklin and Thomas Sydenham were suffered from gouty arthritis (Chen \& Schumacher, 2008). It is an olden day disease which is also called as unwalkable disorder where uric acid level in the serum seems to be increased in this condition (Rymal \& Rizzolo, 2014). It is caused due to the uric acid deposition in the joints which is in the form of crystal found to be in synovial fluid in the acute condition of gout (Ragab et al., 2017). Major factors that lead to gout are sex and age; other factors are serum uric acid level, medications such as aspirin, organ transplant, alcohol consumption, diet and obesity. Some of the diseases associated with gout are type-2 diabetes, hyperuricemia, hypertension and cardiovascular disease (CVD) (Neogi et al., 2015).

It is evident from the literature that gout has increased in prevalence in which the percentage exceeded up to $10 \%$ for males and $6 \%$ for females in many countries. According to the Aotearoa New Zealand Health Tracker (ANZHT) gout

*Author for correspondence: Sabina Evan Prince, School of Biosciences and Technology, VIT, Vellore-632014, India. Email-eps674@gmail.com 
prevalence in New Zealand was observed as 4\%, particularly people in the region of Pacific and Maori were found to be at high rates (Robinson, 2018). According to the International League of Nations Against Rheumatism, Community Oriented Program for Control of Rheumatic Diseases (ILAR-COPCORD) gout prevalence in India is $15.8 \%$ especially in western India (Chopra et al., 2001). Other countries like Germany, USA, Europe, Switzer land, Australia, Israel, South Korea, Japan and Canada, it arises from 6\% to $10 \%$. This is all because of less diet, food habitat, obesity due to no utilization of exercises and syndrome X (Kuo et al., 2015).

There are several mechanisms behind gout in which monosodium urate (MSU) crystal interacts with phagocytic cells that results in an inflammatory response which in turn induces the release of cytokines such as interleukin -1 beta (IL-1B), interleukin -6 (IL-6), interleukin -8 (IL8), interleukin -18 (IL-18) and Tumor Necrosis Factor (TNF- $\alpha$ ) by macrophages (Busso \& So, 2010) but in gout condition it causes inflammation. Microsomal Prostaglandin E synthase-1 (mPGES-1) and Cyclooxygenase-2 (COX-2) are the enzymes that induce Prostaglandin E2 (PGE2) in the mesangial cell (S. Li et al., 2017). Lysis of lysosomal membrane by the neutrophils infiltration in synovium that releases elevated levels of lysosomal enzymes by leukocytes. Leukotriene B4 (LTB4) gets generated by the activation of Arachidonate 5-lipoxygenase (ALOX5) pathway that oxygenates the LTB4 to form dicarboxylic-LTB4 and trihydroxic-LTB4 and result in calcium mobilization, degranulation and aggression of neutrophils (Rae et al., 1982). ThromboxaneA2 (TXA2) raised from platelets bring out by thromboxane-A-synthase (TXAS) which increases the platelet agglomeration during the bloodstream (Gryglewski et al., 1978). These lead to the formation of free radicals, the increasing level of oxygen-derived free radicals or reactive oxygen species (ROS) by antioxidants are resulting to be acute gout (Rasool \& Varalakshmi, 2006).

The common drugs prescribed for gout act in their following ways against the inflammation like Colchicine block the generation of LTB4, Corticosteroids drug acts against inflammation through Adreno corticotropic hormone (ACTH) and Non-Steroidal Anti-Inflammatory Drugs
(NSAID) such as indomethacin, ibuprofen, naproxen and sulindac has analgesic medical property (Cronstein \& Sunkureddi, 2013). These drugs have severe side effects such as chronic kidney diseases, gastrointestinal toxicity and high blood pressure (BP) upon abiding consumption (Schlesinger et al., 2011). Allopurinol, febuxostat, Probenecid and benzbromarone are the xanthine oxidase inhibitors that are used as a uricosuric agent (decrease uric acid level). These drugs have also shown side effects like hypersensitivity arthralgia, nausea, diarrhea and damages in the stomach and intestine (Eggebeen, 2007; Udhaya Lavinya et al., 2016). Thus, a potential drug against gouty arthritis has to be developed without any side effects.

Guar is a plantae kingdom that grows up to 3 $\mathrm{m}$. It is a single stem plant where the leaves and stem of this plant are hairy. The botanical name of the guar plant is Cyamopsis tetragonoloba which belongs to Leguminaceae family and other names are guvar and guwar (Whistler \& Hymowitz, 1979). It is tolerant of drought, salinity and grows good in alkaline $(\mathrm{pH}$ 8) conditions (Anderson, 2002). It can be found widely in India and Pakistan. The seeds can be seen in the plant which is called Guar gum or guaran and it has numerous medical applications. The guar gum consists of protein-rich germination, large endosperm, galactomannan, good hydrogen bonding and it is viscous in water (Mudgil et al., 2014). In the world, India is the largest producer of $80 \%$ of guar gum (Trostle, 2013). It has a variety of industrial applications like paper industry, explosives as a waterproofing agent, hydraulic fracturing, textile industries in sizing and printing, cosmetics in toothpaste thickening and pharmaceuticals in laxative production (Review, 2012). Food applications such as in bread production because of improvement in shelf life and prevention of syneresis, thickening of dairy products and soups, as a binder in meat and improves stability in salad and ketchup (Morris, 2010). It has been also used as a matrix in tablets like diclofenac sodium and rofecoxib that are prescribed for colorectal cancer (Al-Saidan et al., 2005; Chavda et al., 2012). Medical benefits of the aqueous extract of stem, leaf and seeds of Cyamopsis tetragonoloba includes great antioxidant activities and antimicrobial capacities (Moteriya et al., 2015). The methanol extract of Cyamopsis tetragonoloba seed showed 
antitumor activity against intestinal carcinoma and human prostate carcinoma it also acts against mycoplasms such as Mycoplasmbovis and $M$. gallisepticum (Sharma et al., 2017). The aqueous seed extract of Cyamopsis tetragonoloba has also treated alloxan-induced diabetes in Wistar rats (Mukhtar et al., 2004) as well as it showed the better effect of antihyperlipidemic and antihyperglycemic activity than the glibenclamide in streptozocin (STZ)-induced diabetes in rats (Samarghandian et al., 2012). Other medicinal beneficial effects include analgesic (Castro et al., 2007), antiinflammatory (Gamal-Eldeen et al., 2006) and antiulcer (Borrelli \& Izzo, 2000) abilities. It has weight reducing property that is evident from the patient treated with Cyamopsis tetragonoloba had seemed to reduce body weight by the reduction of fat, cholesterol and triglycerides (Krotkiewski, 1984) subsequently it is used a good dietary supplement. Earlier research has not demonstrated the anti-inflammatory activity of Cyamopsis tetragonoloba against gouty arthritis, we hypothesized that Cyamopsis tetragonoloba would be having potential activity against MSU-induced gout arthritis. Thus, this study was performed to analyze the significant effect of aqueous seed extract of Cyamopsis tetragonoloba (ASECT) against MSU-induced gout inflammation in rats. The NSAID drug indomethacin was used as a standard for comparison purposes to identify the beneficial effects of ASECT.

\section{MATERIALS AND METHODS}

\section{Drugs and chemicals}

A powdered form of Guar gum was purchased from Nature Vit, Jodhpur, India which was confirmed to have the purity and was stored at room temperature. The powdered form of Guar gum is from the seed of Cyamopsis tetragonoloba. It was dissolved in distilled water $\left(\mathrm{dH}_{2} \mathrm{O}\right)$ in 1:10 ratio $\mathrm{w} / \mathrm{v}$, dissolved solution of the aqueous solution was incubated for $24 \mathrm{~h}$ at $40{ }^{\circ} \mathrm{C}$, then the solution was filtered by Whatman paper and the filtrate was collected and stored in cold temperature. The dissolving of the sample was verified and no clumping was observed. The filtrate was extracted to get a yield of $10 \%(\mathrm{w} / \mathrm{w})$. Indomethacin was purchased from the Jagsonpal
Pharmaceuticals Ltd., Rudrapur, Uttarakhand, India. Diagnostic kits for urea, uric acid and creatinine were obtained from Auto Span Diagnostics Ltd., Surat, Gujarat, India. Lysosomal enzymes, Lipid peroxidation and antioxidant parameters were performed following the standard protocols.

\section{Animals}

Thirty female albino Wistar rats about the average weight of $300 \mathrm{~g}$ were provided by the Vellore Institute of Technology, Vellore, Tamil Nadu, India. Animals were acclimatized properly with the pathogen-free room, under-maintained temperature and laboratory conditions for $12 \mathrm{~h}$ light/dark cycle for a week and fed with commercially available standard pellets from Hindustan Lever Ltd, Mumbai, India and processed water was freely provided to the animals. The following experimental protocol was approved by the ethical committee (VIT/IAEC/17/Feb2020/11), VIT, Vellore which was carried out according to Indian CPCSEA guidelines.

\section{Synthesis of MSU}

MSU crystals were synthesized by mixing with the $4 \mathrm{~g}$ of uric acid in $800 \mathrm{ml}$ of water and $9 \mathrm{ml}$ of $0.5 \mathrm{~N} \mathrm{NaOH}$. The solutions were adjusted to a $\mathrm{pH}$ of 8.9 and heated in a water bath at $60^{\circ} \mathrm{C}$, then it was cooled overnight at under cold temperature and was washed and dried (Lemos Lima et al., 2015). At last, needle-like MSU crystals were seen under the microscope (Figure 1) which was suspended in sterile saline at the concentration of $20 \mathrm{mg} / \mathrm{ml} .0 .2 \mathrm{ml}(4 \mathrm{mg})$ of MSU was induced by intradermal injection into the right footpad (Sabina et al., 2011; Udhaya Lavinya et al., 2016).

\section{Animal grouping and MSU inflammation in the rat}

The animals were divided into 5 groups with the 6 rats each and administrated as follows:

Group I: Normal control (normal saline, orally for 3 days).

Group II: MSU (4.0 mg/0.2 ml intradermal) alone on $1^{\text {st }}$ day.

Group III: MSU (4.0 mg/0.2 ml intradermal) on $1^{\text {st }}$ day + ASECT $(500 \mathrm{mg} / \mathrm{kgb} . \mathrm{w}$, p.o.) for all 3 days. 
Group IV: MSU (4.0 mg/ $0.2 \mathrm{ml}$ intradermal) on $1^{\text {st }}$ day + ASECT $(1000 \mathrm{mg} / \mathrm{kgb} . \mathrm{w}$, p.o.) for all 3 days.

Group V: MSU $\left(4.0 \mathrm{mg} / 0.2 \mathrm{ml}\right.$ intradermal) on $1^{\text {st }}$ day + Indomethacin (3 mg/kg b.w, p.o.).

ASECT and Indomethacin were orally administered for 3 days, on the $1^{\text {st }}$ day all animals expect group I was injected with MSU into the right footpad $1 \mathrm{~h}$ before drug administration. On the $4^{\text {th }}$ day all the animals were sacrificed to perform analysis. There is no standardized dose for the studies of Cyamopsis tetragonoloba on inflammation, so we had used based on experimentation. The $\mathrm{IC}_{50}$ value is not studied. The guar gum sample was freshly prepared on each day of the experiment.

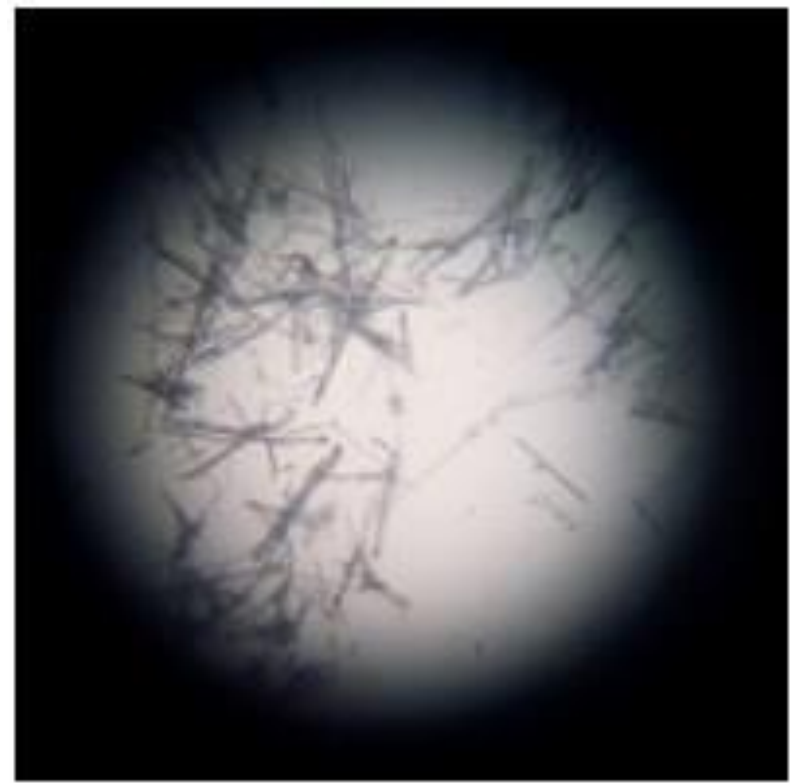

Figure 1. Microscopical view of MSU crystals. Needle shaped structure represent the presence of MSU crystal

\section{Weight assessment}

The weight of each rat was examined in the unit of a gram (g) on all day ( $1^{\text {st }}$ to $4^{\text {th }}$ day) before the drug administration until the sacrifice of rats.

\section{Assessment of inflammation}

Inflammation was quantified by using a digital vernier caliper to measure the thickness of the rat's paw at different intervals for 3 days. At the end of the period, rats were sacrificed by euthanasia (ketogenic injection). The animals were sacrificed according to the standard CPCSEA (Committee for the Purpose of Control and Supervision of Experiments on Animals) guidelines. Blood from each rat was collected through retro-orbital plexus. The serum was prepared from the coagulated blood by centrifugation at $3000 \mathrm{rpm}$ for 10 minutes. The organs such as the liver and spleen were dissected, rinsed by phosphate buffers solution before and stored at $4^{\circ} \mathrm{C}$ in $0.89 \%$ of $\mathrm{NaCl}$. The organs were homogenized with $10 \mathrm{ml}$ of $0.1 \mathrm{M}$ Tris- $\mathrm{HCl}$ buffer (Udhaya Lavinya et al., 2016). Serum and the homogenate tissue of spleen and liver were used for analyzing lysosomal enzymes, lipid peroxidation and antioxidant status. Separated serum was used for analyzing the effect of biochemical parameters such as urea, uric acid and creatinine.

\section{Effect of ASECT and indomethacin on serum biochemical parameters}

Renal markers such as urea, uric acid and creatinine in serum were evaluated to assess kidney damage. This serum biochemical assay was performed by following the kit manufacturer's procedure and the commercial kit was obtained from Auto Span Diagnostics Ltd., India. The activity of the lysosomal enzyme acid phosphatase (ACP) was examined in the samples such as serum, liver and spleen that were assayed using the King-Armstrong method (King et al., 1951).

\section{Effect of ASECT and indomethacin on Antioxidant Status}

Thiobarbituric acid (TBA) was used in accomplishing Lipid peroxidation (LPO) of the liver and spleen by the method of Hogberg et al. (1974). The activity of antioxidant enzymes such as Superoxide dismutase (SOD), catalase (CAT) and Reduced Glutathione (GSH) in liver, spleen and serum were examined by standard protocols (Marklund \& Marklund, 1974; Rotruck et al., 1973; Sinha, 1972).

\section{Histopathological examinations}

After sacrifice, the paw from each rat was taken and rinsed in PBS buffer and stored in 10\% formalin for further studies. The paw bone of rats was sectioned by microtome for about $5 \mu \mathrm{m}$ thickness. Then pawbone tissue was stained with Haematoxylin and Eosin ( $\mathrm{H} \& \mathrm{E})$ which was then examined under a microscope for histological variations. 


\section{Statistical analysis}

The result obtained was expressed as a mean and standard deviation ( \pm ). One-way ANOVA analyzed by the software called GraphPad InStat3 and determine a significant difference $(p<0.05)$ between the groups where Student NewmanKeul's test was used (Kim, 2015).

\section{RESULTS}

\section{Effect of ASECT and indomethacin on body weight of MSU-induced arthritis in rats}

The weight of the rats has significantly $(\mathrm{p}<0.05)$ increased in a normal control group and indomethacin treated group which was shown in the figure. Rats induced with MSU crystal and treated with ASECT show significant $(\mathrm{p}<0.05)$ reduction of weight in rats (Figure 2).

\section{Effect of ASECT and indomethacin on paw volume of $M S U$-induced arthritis}

Figure 3 and Figure 4 are demonstrating the effect of ASECT and indomethacin on the paw volume of MSU-induced arthritis rats. Group I show no difference in paw volume of rats wherein group II paw volume of rats significantly $(p<0.05)$ increased on every day basis. ASECT treated groups such as group III \&group IV showed significant $(\mathrm{p}<0.05)$ increase on paw volume in MSU-induced arthritis rats till $48^{\text {th }}$ hour and was significantly $(p<0.05)$ reduced and indomethacin treated rats also showed a similar effect.

\section{Effect of ASECT and indomethacin on renal markers of $M S U$-induced arthritis in rats}

The level of the kidney markers such as urea, uric acid and creatinine were significantly $(p<0.05)$ raised in the serum of MSU-induced arthritis rats, where the administration of ASECT showed the significant $(p<0.05)$ reduction in raised level of kidney markers and the reduced levels were similar to the normal control group (Figure 5).

\section{Effect of ASECT and indomethacin on antioxidant enzymes of $M S U$-induced arthritis in rats}

MSU induced rats showed significant $(p<0.05)$ decrease in antioxidant enzymes such as SOD, CAT and GSH after the administration of ASECT the range of antioxidant enzymes in liver, spleen and serum significantly $(\mathrm{p}<0.05)$ increased subsequently showing near normal range compared to the control group. The standard drug indomethacin has also shown approximate antioxidant status (Table 1).

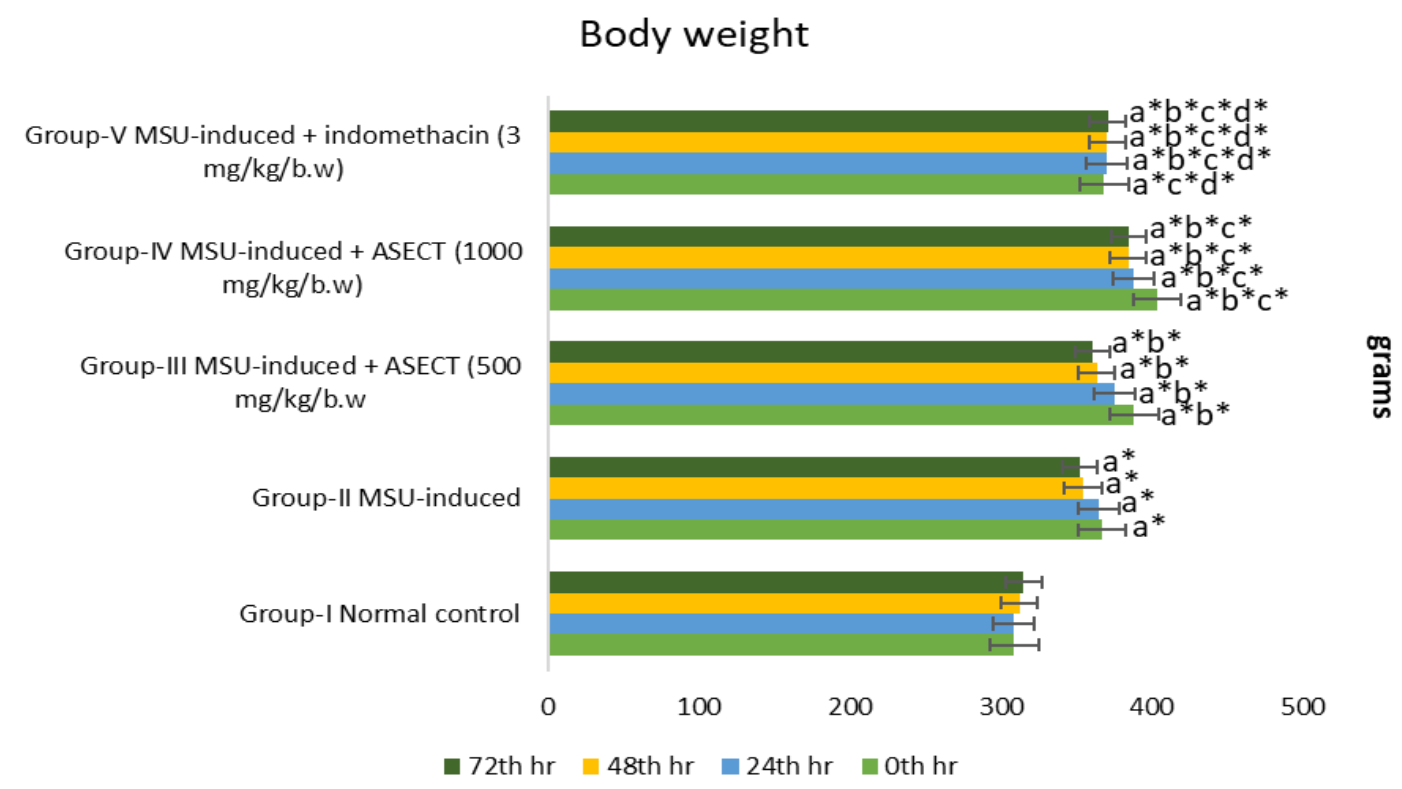

Figure 2. Effect of ASECT and indomethacin on body weight. Every value is expressed in mean \pm SD ( $n=6)$. The comparisons were made as follows: a) Group I vs Group II, III, IV \& V; b) Group II vs GroupIII, IV \& V; c) Group III vs Group-IV \& V; d) Group IV vs Group V. One-way ANOVA was followed to analyze the statistical analysis. The $(*)$ symbol represents the statistical significance $(\mathrm{p}<0.05)$ between the groups. Student Newman-Keul's test was followed. 


\section{Paw volume}

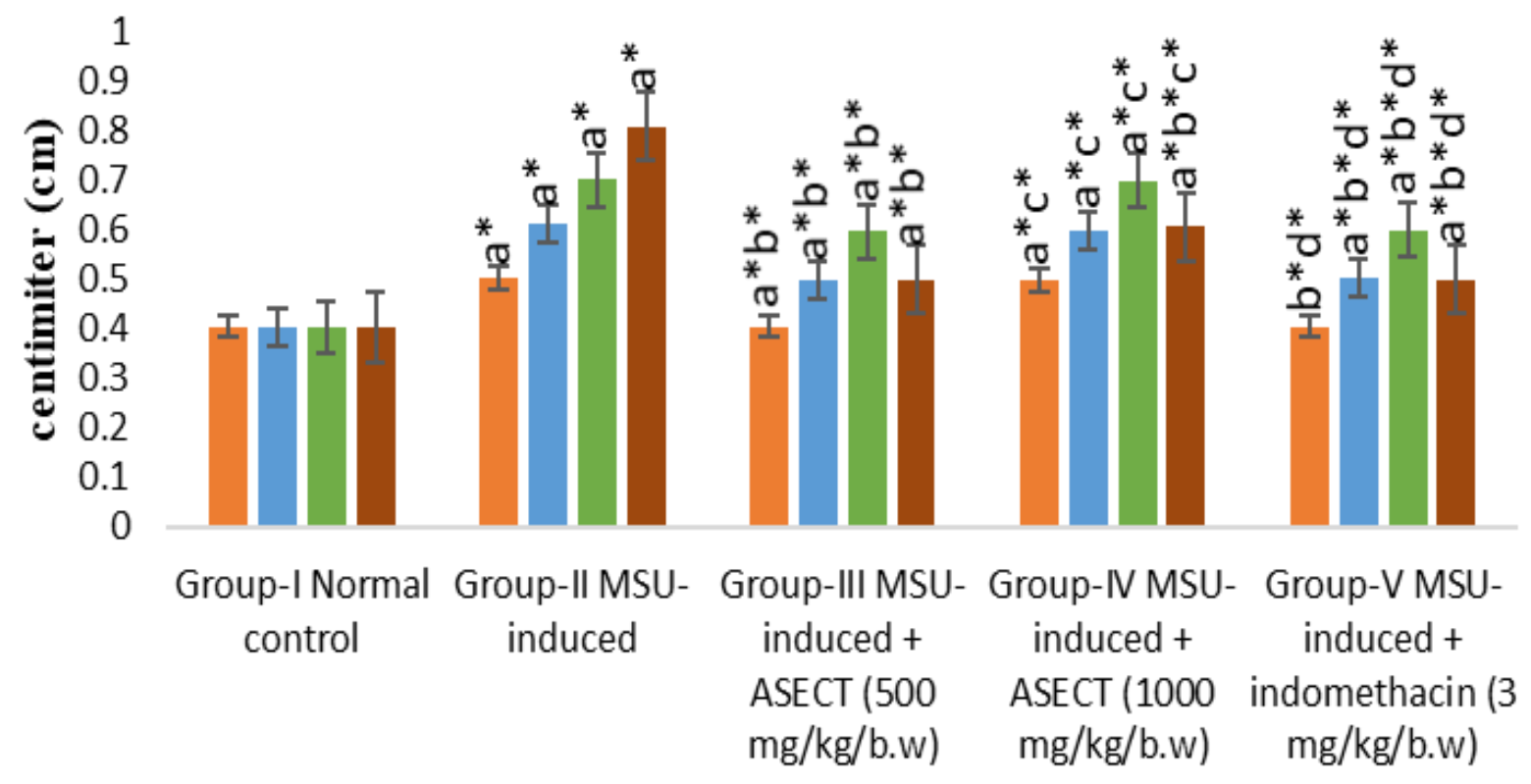

0th $\mathrm{hr} \quad$ 24th $\mathrm{hr} \quad$ 48th $\mathrm{hr} \quad$ 72th hr

Figure 3. Effect of ASECT and indomethacin on paw volume. Every value is expressed in mean \pm SD $(\mathrm{n}=6)$. The comparisons were made as follows: a) Group I vs Group II, III, IV \& V; b) Group II vs GroupIII, IV \& V; c) Group III vs Group-IV \& V; d) Group IV vs Group V. One-way ANOVA was followed to analyze the statistical analysis. The $(*)$ symbol represents the statistical significance $(p<0.05)$ between the groups. Student Newman-Keul's test was followed.

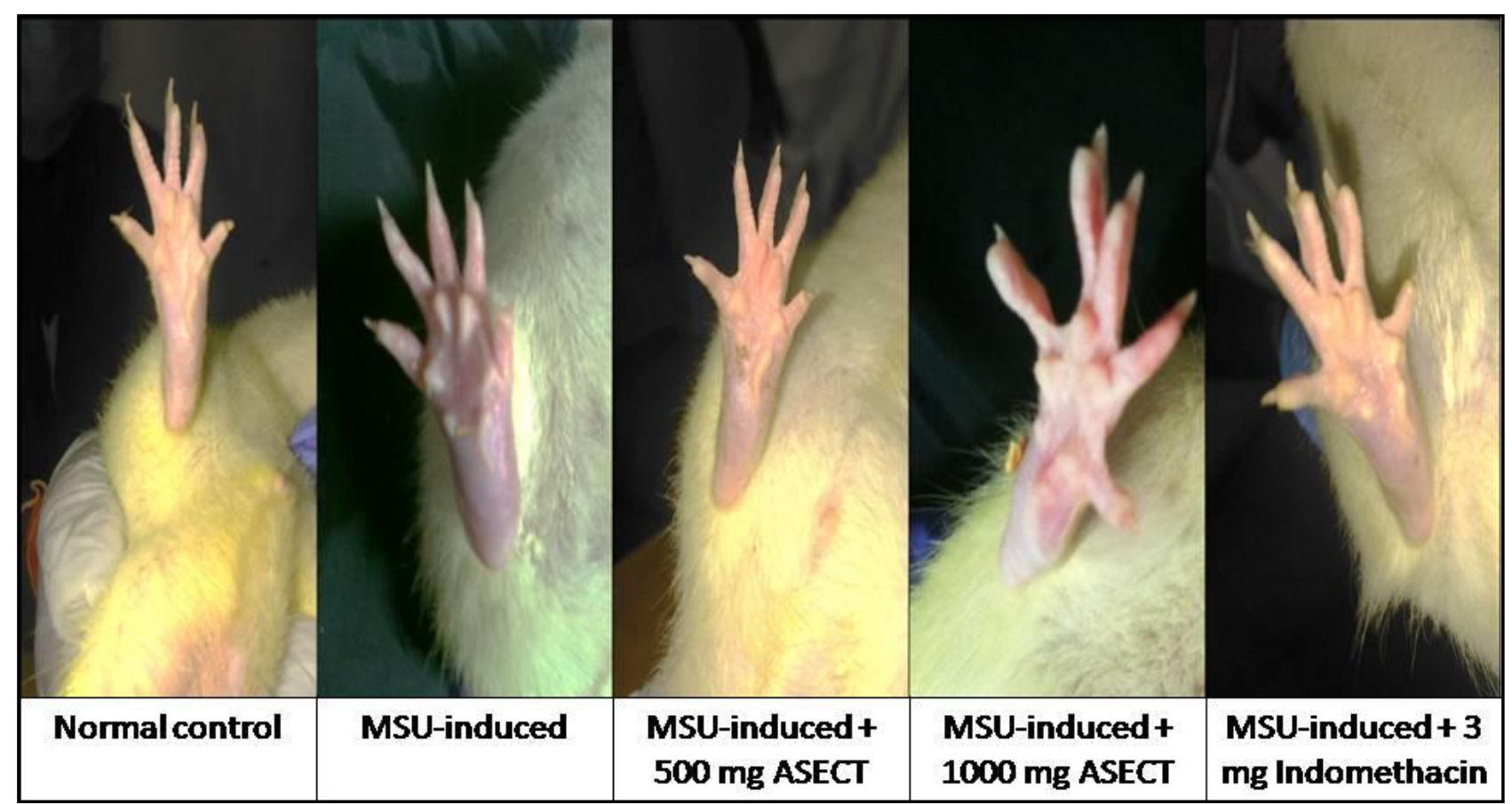

Figure 4. Effect of ASECT and Indomethacin on paw volume of MSU-induced arthritis. Normal control group: Normal paw volume, MSU-induced group: Increased paw volume, MSU-induced + ASECT group: Normal paw volume and MSU-induced + indomethacin: Slight increased paw volume. The picture of the rats paw was taken on the $4^{\text {th }}$ day of the experiment. 


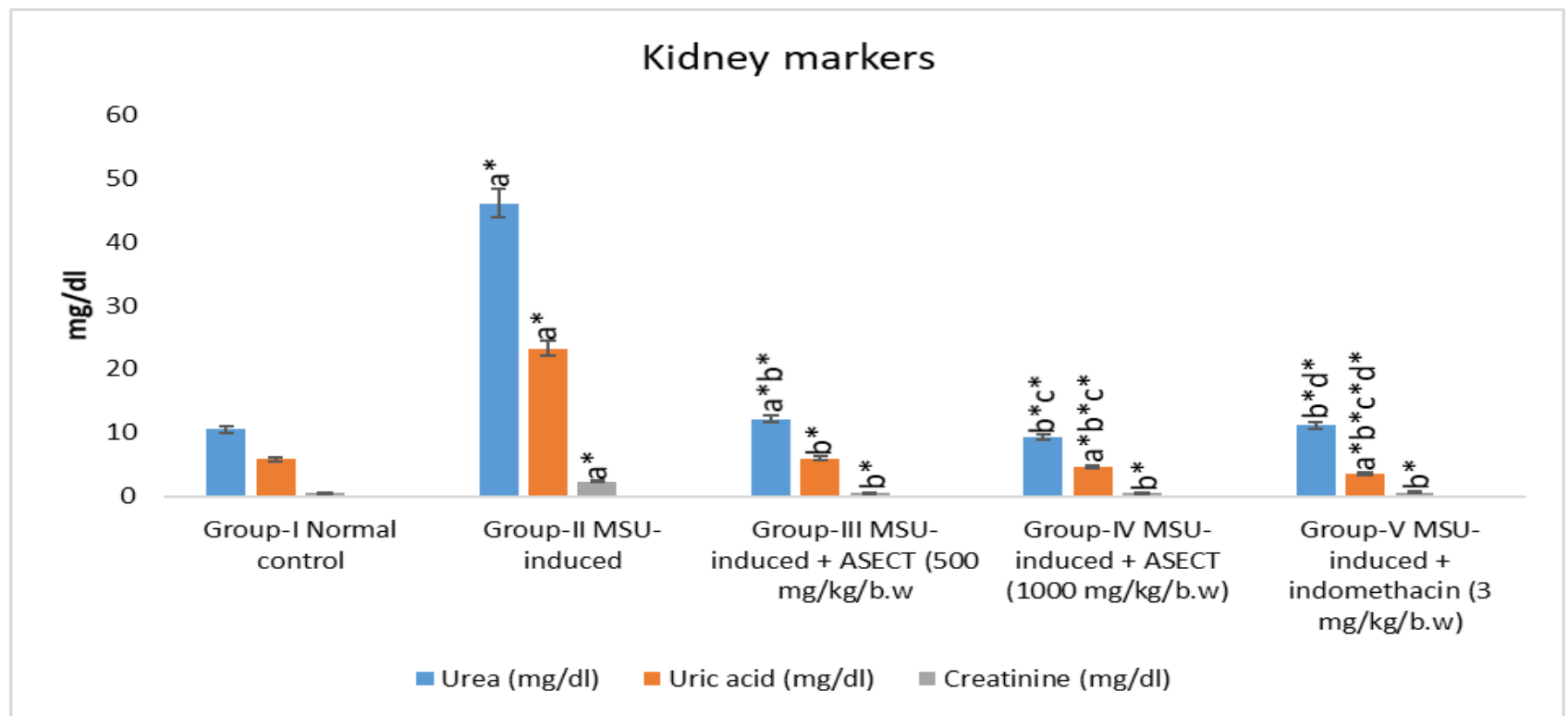

Figure 5. Effect of ASECT and indomethacin on renal markers. Every value is expressed in mean \pm SD $(\mathrm{n}=6)$. The comparisons were made as follows: a) Group I vs Group II, III, IV \& V; b) Group II vs GroupIII, IV \& V; c) Group III vs Group-IV \& V; d) Group IV vs Group V. One-way ANOVA was followed to analyze the statistical analysis. The $(*)$ symbol represents the statistical significance $(p<0.05)$ between the groups. Student Newman-Keul's test was followed.

Table 1. Effect of ASECT and Indomethacin on antioxidant enzymes of MSU-induced arthritis in rats.

\begin{tabular}{|c|c|c|c|c|c|}
\hline Enzymes & $\begin{array}{l}\text { Group-I } \\
\text { Normal } \\
\text { control }\end{array}$ & $\begin{array}{c}\text { Group-II } \\
\text { MSU-induced } \\
(4 \\
\mathrm{mg} / \mathrm{kg} / \mathrm{b.w})\end{array}$ & $\begin{array}{c}\text { Group-III } \\
\text { MSU-induced }+ \\
500 \mathrm{mg} / \mathrm{kg} \text { of } \\
\text { b.w of ASECT }\end{array}$ & $\begin{array}{c}\text { Group-IV } \\
\text { MSU-induced }+ \\
1000 \mathrm{mg} / \mathrm{kg} \text { of } \mathrm{b} . w \\
\text { of ASECT }\end{array}$ & $\begin{array}{c}\text { Group-V } \\
\text { MSU-induced }+3 \\
\text { mg/kgof b.w of } \\
\text { indomethacin }\end{array}$ \\
\hline \multicolumn{6}{|c|}{ SOD (U/min/mg protein): } \\
\hline Liver & $64.735 \pm 0.218$ & $25.202 \pm 0.181 \mathrm{a}^{*}$ & $63.68 \pm 0.207 \mathrm{a} * \mathrm{~b} *$ & $63.157 \pm 0.275 \mathrm{a}^{*} \mathrm{~b}^{*}$ & $73.783 \pm 0.231 \mathrm{a}^{*} \mathrm{~b}^{*} \mathrm{c}^{* *}$ \\
\hline Spleen & $34.550 \pm 14.821$ & $19.687 \pm 0.237 a^{*}$ & $46.805 \pm 0.37 b^{*}$ & $48.217 \pm 0.222 b^{*}$ & $45.73 \pm 1.751 b^{*}$ \\
\hline Serum & $57.317 \pm 0.248$ & $21.650 \pm 0.187 a^{*}$ & $55.317 \pm 0.248 \mathrm{a}^{*} \mathrm{~b} *$ & $57.233 \pm 0.301 b^{*} c^{*}$ & $54.315 \pm 0.378 \mathrm{a}^{*} \mathrm{~b} * \mathrm{c} * \mathrm{~d} *$ \\
\hline \multicolumn{6}{|c|}{ Catalase (U/min/mg protein): } \\
\hline Liver & $53.298 \pm 0.263$ & $26.268 \pm 0.159 \mathrm{a}^{*}$ & $55.257 \pm 0.199 \mathrm{a}^{*} \mathrm{~b}^{*}$ & $57.858 \pm 0.157 a^{*} b^{*} c^{*}$ & $54.833 \pm 0.224 a^{*} b^{*} \mathrm{~d}^{*}$ \\
\hline Spleen & $55.307 \pm 0.143$ & $20.568 \pm 0.696 \mathrm{a}^{*}$ & $56.938 \pm 0.251 \mathrm{a}^{*} \mathrm{~b}^{*}$ & $59.183 \pm 0.231 \mathrm{a}^{*} \mathrm{~b}^{*} \mathrm{c}^{*}$ & $58.333 \pm 0.258 \mathrm{a}^{*} \mathrm{~b}^{*} \mathrm{c}^{*}$ \\
\hline Serum & $64.453 \pm 0.316$ & $25.255 \pm 0.21 \mathrm{a}^{*}$ & $65.645 \pm 0.449 \mathrm{a}^{*} \mathrm{~b} *$ & $67.307 \pm 0.261 \mathrm{a}^{*} \mathrm{~b}^{*} \mathrm{c}^{*}$ & $64.343 \pm 0.149 b^{*} c^{*} d^{*}$ \\
\hline \multicolumn{6}{|c|}{ GSH (nmol/mg protein): } \\
\hline Liver & $25.352 \pm 0.237$ & $12.278 \pm 0.179 \mathrm{a}^{*}$ & $26.257 \pm 0.165 a^{*} b^{*}$ & $21.005 \pm 0.381 \mathrm{a}^{*} \mathrm{~b}^{*} \mathrm{c} *$ & $21.808 \pm 0.181 a^{*} b^{*} c^{*} d *$ \\
\hline Spleen & $16.55 \pm 0.187$ & $9.368 \pm 0.201 \mathrm{a}^{*}$ & $16.853 \pm 0.162 b^{*}$ & $19.360 \pm 0.187 a^{*} b^{*} c^{*}$ & $14.407 \pm 0.142 a^{*} b^{*} c^{*} d^{*}$ \\
\hline Serum & $22.928 \pm 0.185$ & $12.263 \pm 0.191 \mathrm{a}^{*}$ & $29.225 \pm 0.198 \mathrm{a}^{*} \mathrm{~b}^{*}$ & $25.48 \pm 0.266 a^{*} b^{*} c^{*}$ & $25.420 \pm 0.153 a^{*} b^{*} c^{*}$ \\
\hline
\end{tabular}

Every value is expressed in mean $\pm \mathrm{SD}(\mathrm{n}=6)$. The comparisons were made as follows: a) Group I vs. Group II, III, IV \& V; b) Group II vs. Group-III, IV \& V; c) Group III vs. Group-IV \& V; d) Group IV vs. Group V. One-way ANOVA was followed to analyze the statistical analysis. The $\left(^{*}\right)$ symbol represents the statistical significance $(\mathrm{p}<0.05)$ between the groups. Student Newman-Keul's test was followed.

\section{Effect of ASECT and indomethacin on lipid} peroxidation of $M S U$-induced arthritis in rats

Table 2 shows the effect of ASECT in the level of lipid peroxidation in the sample such as the liver, spleen and serum of normal control and MSUinduced arthritis rats. Lipid peroxidation level of group-II shows elevated significant $(p<0.05)$ level, where administration of ASECT and indomethacin reduced the elevated level and that was similar to the group-I level.

\section{Effect of ASECT and indomethacin on acid} phosphatase of MSU-induced arthritis in rats The effect of ASECT on the activity of acid phosphatase in MSU-induced arthritis rats where represented in Table 3. The level of acid phosphatase in the sample such as liver, spleen 
and serum showed significant $(\mathrm{p}<0.05)$ increase. The rats treated with ASECT and indomethacin have normalized the abnormal level of acid phosphatase. Standard drug indomethacin was used to compare the effect of ASECT.

\section{Effect of ASECT and indomethacin on the histopathological approach of $M S U$-induced arthritis in rats}

Figure 6 shows the paw bone histopathology. The control rats (group I) shown normal morphology (Figure 6a). The MSU-induced rats (group II) histology shown granulation tissue erosion, presence of inflammation and absence of collagen (Figure 6b). Where ASECT administrated rats (group III and group IV) were found to show normal histology with proper joint space and regular collagen of the paw bone (Figure $6 \mathrm{c}$ and Figure 6d). The effect of ASECT was compared with the standard drug (indomethacin) administrated rats (group V) which shown normal regular collagen with mild osteoblastic activity changes (Figure 6e).

Table 2. Effect of ASECT and Indomethacin on lipid peroxidation of MSU-induced arthritis in rats

\begin{tabular}{|c|c|c|c|c|c|}
\hline $\begin{array}{c}\text { LPO } \\
(\mathrm{mg} / \mathrm{dl})\end{array}$ & $\begin{array}{l}\text { Group-I } \\
\text { Normal } \\
\text { control }\end{array}$ & $\begin{array}{c}\text { Group-II } \\
\text { MSU-induced } \\
(4 \\
\mathrm{mg} / \mathrm{kg} / \mathrm{b.w})\end{array}$ & $\begin{array}{c}\text { Group-III } \\
\text { MSU-induced } \\
+500 \mathrm{mg} / \mathrm{kg} \text { of } \\
\text { b.w of ASECT }\end{array}$ & $\begin{array}{c}\text { Group-IV } \\
\text { MSU-induced + } \\
1000 \mathrm{mg} / \mathrm{kg} \text { of } \\
\text { b.w of ASECT }\end{array}$ & $\begin{array}{c}\text { Group-V } \\
\text { MSU-induced + } \\
3 \mathrm{mg} / \mathrm{kg} \text { of } \\
\text { indomethacin }\end{array}$ \\
\hline & & $201 a^{*}$ & 2.363 & 2.545 & 2.502 \\
\hline & & 5.085 & $3.492 \pm 0.202 \mathrm{a} * \mathrm{~b} *$ & $3.562 \pm 0.151 \mathrm{a} * \mathrm{~b} *$ & $2.933 \pm$ \\
\hline Serum & $4.028 \pm 0.183$ & $5.453 \pm 0.129 \mathrm{a}^{*}$ & $4.247 \pm 0.206 \mathrm{~b}^{*}$ & $4.877 \pm 0.172 \mathrm{a}^{*} \mathrm{~b}^{*} \mathrm{c}^{*}$ & $4.043 \pm 0.142 \mathrm{~b} * \mathrm{~d}^{*}$ \\
\hline
\end{tabular}

Every value is expressed in mean \pm SD ( $(n=6)$. The comparisons were made as follows: a) Group I vs. Group II, III, IV \& V; b) Group II vs. Group-III, IV \& V; c) Group III vs. Group-IV \& V; d) Group IV vs. Group V. One-way ANOVA was followed to analyze the statistical analysis. The $(*)$ symbol represents the statistical significance $(\mathrm{p}<0.05)$ between the groups. Student Newman-Keul's test was followed.

Table 3. Effect of ASECT and Indomethacin on Acid phosphatase of MSU-induced arthritis in rats

\begin{tabular}{|c|c|c|c|c|c|}
\hline $\begin{array}{c}\text { ACP } \\
\left(\mu \text { moles } \times 10^{-2}\right)\end{array}$ & $\begin{array}{c}\text { Group-I } \\
\text { Normal } \\
\text { control }\end{array}$ & $\begin{array}{c}\text { Group-II } \\
\text { MSU-induced } \\
(4 \\
\mathrm{mg} / \mathrm{kg} / \mathrm{b} . w)\end{array}$ & $\begin{array}{c}\text { Group-III } \\
\text { MSU-induced } \\
+500 \mathrm{mg} / \mathrm{kg} \\
\text { of b.w of } \\
\text { ASECT }\end{array}$ & $\begin{array}{c}\text { Group-IV } \\
\text { MSU-induced } \\
+1000 \mathrm{mg} / \mathrm{kg} \\
\text { of b.w of } \\
\text { ASECT }\end{array}$ & $\begin{array}{c}\text { Group-V } \\
\text { MSU-induced } \\
+3 \mathrm{mg} / \mathrm{kg} \text { of } \\
\text { indomethacin }\end{array}$ \\
\hline & & & $2.268 \pm 0.197 \mathrm{~b}^{*}$ & $2.343 \pm 0.144 b^{*}$ & \\
\hline & & & 3.452 & & $3.237 \pm 0.102 b^{*}$ \\
\hline Serum & $0.156 \pm 0.018$ & $0.258 \pm 0.055$ & $0.166 \pm 0.019$ & $0.151 \pm 0.025$ & $0.193 \pm 0.096$ \\
\hline
\end{tabular}

Every value is expressed in mean \pm SD ( $\mathrm{n}=6)$. The comparisons were made as follows: a) Group I vs. Group II, III, IV \& V; b) Group II vs. Group-III, IV \& V; c) Group III vs. Group-IV \& V; d) Group IV vs. Group V. One-way ANOVA was followed to analyze the statistical analysis. The $\left(^{*}\right)$ symbol represents the statistical significance $(\mathrm{p}<0.05)$ between the groups. Student Newman-Keul's test was followed.

\section{DISCUSSION}

Gout is an acute inflammation from the ancient period; it may be due to improper exercises, diets we follow and food habitats. When the serum uric acid level increased in our body it leads to deposition of MSU in joints and renal tissues that induces cytokines which is responsible for inflammation in gout. The prevalence of gout is significantly increasing every year all over the world (L. Li et al., 2017). The present study is evident for the successful confirmation of antiarthritic activity in the effect of ASECT. The analysis of body weight, paw volume, biochemical parameters, antioxidant, lipid peroxidation, acid phosphatase and histopathological approaches were found to be normalized by ASECT.

Bodyweight of the MSU-induced rats was significantly $(p<0.05)$ reduced due to the pain induced by MSU, at the condition of acute gout the animals were unable to bear the pain thus it hardly walks, stretches and food intake such condition is called as allodynia, it may also lead to 
the malnutrition (Hoffmeister et al., 2014). ASECT administration rats body weight also significantly $\quad(p<0.05) \quad$ reduced, which demonstrates that Cyamopsis tetragonoloba has weight reducing property as well as curing ability. Indomethacin administration rats body weight was normally increased by the reasons for weight gaining property where normal control rats body weight was normal (Fjære et al., 2014). An elevated level of uric acid in serum due to MSU crystals are known to cause renal damage which is because of uricase inhibition. In those condition renal kidney markers such as urea, uric acid and creatinine may be leaked out into the blood. This is the reason were markers seem to be significantly $(p<0.05)$ increased in MSU induced rats (Kim et al., 2014). Our drug has reduced the level of markers in rats and recovered the renal function after the ASECT administration.

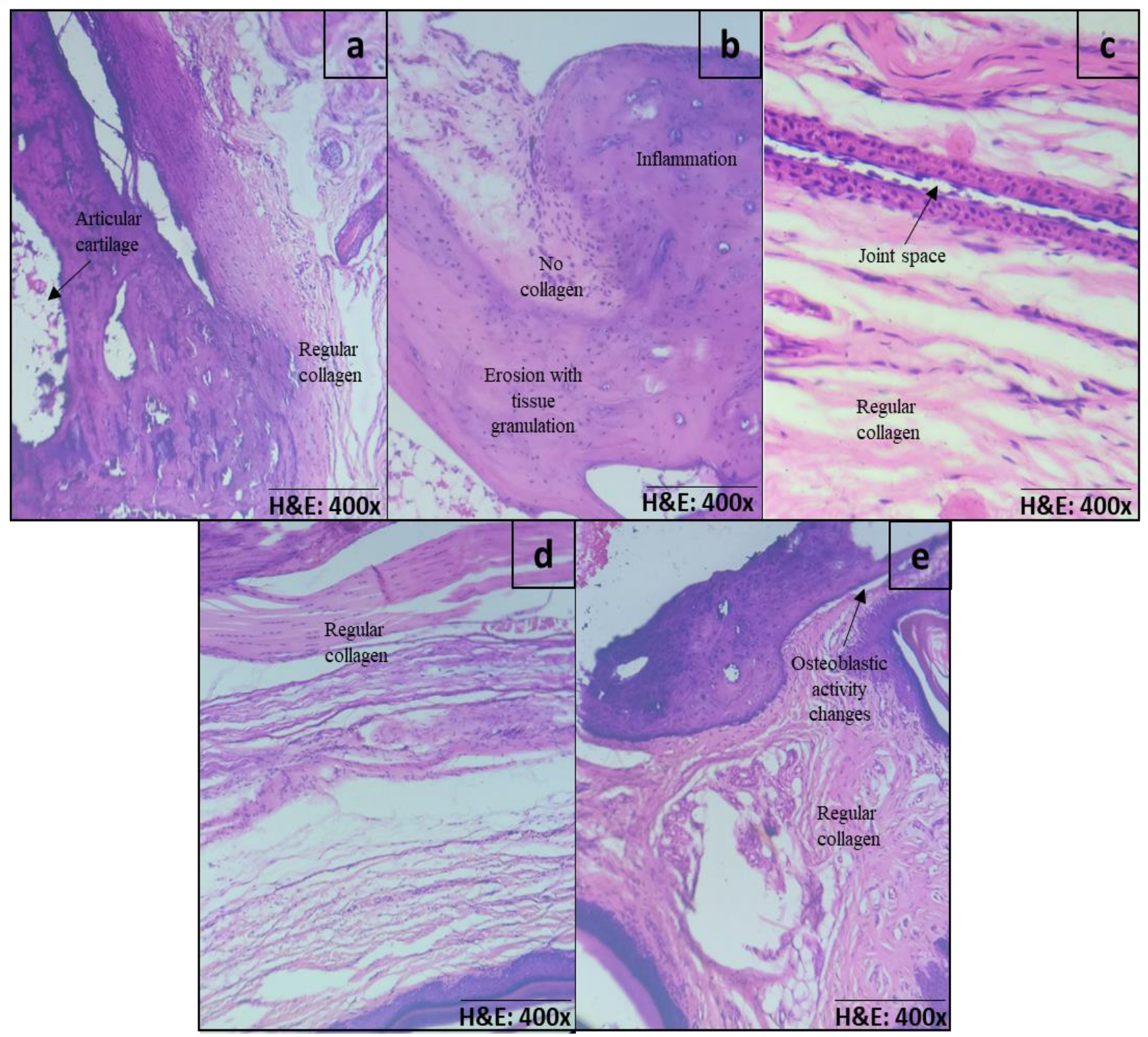

Figure 6. Histopathological approach of paw bone. H \& E stained histology in 400x are studied as follows a)normal control - paw bone morphology showing normal histology with regular collagen and proper articular cartilage; b) MSU-induced - paw bone histology showing erosion with granulated tissues and inflammation with no collagen; c) MSU-induced + treated with $500 \mathrm{mg} / \mathrm{kg}$ of b.w of ASECT - paw bone histology showing regular collagen and proper joint space, d) MSU-induced + treated with $1000 \mathrm{mg} / \mathrm{kg}$ of b.w of ASECT - bone histology showing regular collagen; e) MSU-induced + treated with $3 \mathrm{mg} / \mathrm{kg}$ of b.w of ASECT - bone histology showing normal morphology and regular collagen with mild osteoblastic activity change. 
The formation of paw edema or elevated paw volume in rats is due to MSU-induced inflammation associated with the vascular leakage syndrome (VLS) that induce leukocytes to cast out the lysosomal enzymes by disrupting its membrane, which leads to inflammations due to inflammatory mediator (PGE2, LTB4 and TXA2) synthesis (Moilanen et al., 2015; Sabina et al., 2011). The drugs which can reduce the level of oozing out lysosomal enzyme into the blood will have anti-arthritic properties where our drug ASECT significantly $(\mathrm{p}<0.05)$ reduced paw volume and lysosomal enzyme level, thus it is proved that ASECT prevents the vascular leakage and terminated the inflammation. LPO level was found to be high in MSU induced rats which is due to neutrophil infiltration and monocyte that induce an inflammatory response that in turn leads to lipids degradation in the cell membrane at the time of inflammation. The antioxidant enzymes such as SOD, CAT and GSH act against ROS, where the cluster of ROS forms oxidative stress is crucial for significant $(p<0.05)$ decline in antioxidant enzymes in MSU induced rats as acute gout condition (Sabina \& Rasool, 2008). After the administration of ASECT the level of antioxidant enzymes has been raised and LPO level reduced which were similar to the normal control group. It is evident that the effect of ASECT has ROS scavenging and LPO neutralizing property.

The articular cartilage in the bone plays a major role in healing inflammation, recovery by itself where good health is straightforwardly associated with proper joint functions (Sophia Fox et al., 2009). The inflammation is responsible for bone erosion and collagen changes which can be seen in MSU-induced rats histology. Impeding the cytokines or inflammatory responses may suppress the inflammation (van der Heijde, 2011). By the administration of ASECT, it rejuvenated the inflammation in bone tissues with obviated erosion and reclaimed normal collagen. Guar gum was reported to have potential usage on food products like beverages, bakery products, cheese, dairy products and meat products. Its beneficial activities on lowering glucose level and cholesterol levels were also reported. A study on guar gum has stated that it doesn't have any harmful effects even at the dosage of $2500 \mathrm{mg} / \mathrm{kg}$ (Mudgil et al., 2014).

\section{CONCLUSION}

Our present research concludes the effect of ASECT in MSU-induced gout in female Wister albino rats. The reports have declared that administration of ASECT against MSU had good effects such as significantly $(\mathrm{p}<0.05)$ reduced paw volume, renal markers (urea, uric acid and creatinine), LPO and ACP, were also significantly $(\mathrm{p}<0.05)$ raised anti-oxidants (SOD, CAT and GSH) and diminished the inflammation in rats paw bone. Compared to indomethacin, ASECT has shown beneficial effects that could be observed in this research. Hence the present investigation proves that Cyamopsis tetragonoloba has an anti-gout capacity and further additional molecular studies need to be studied to comprehend the mechanism of Cyamopsis tetragonoloba against gout. The limitations of the current research are that the metabolic pathway of Cyamopsis tetragonoloba against gout was not identified and identifying the bonding interaction or chemistry perspective also would help in target specific treatment. Further, the clinical studies could be performed to identify its potential activities. As guar gum is used in many food industries, this would also help to find a novel drug against gout through clinical studies. After clinical studies, the guar gum could be used as beneficial drug for gout.

\section{ACKNOWLEDGEMENTS}

The authors thank VIT for providing 'VIT SEED GRANT' for carrying out this research work.

\section{REFERENCES}

Al-Saidan, S. M., Krishnaiah, Y. S. R., Satyanarayana, V., \& Rao, G. S. 2005. In vitro and in vivo evaluation of guar gumbased matrix tablets of rofecoxib for colonic drug delivery. Current Drug Delivery 2(2): 155-163.

Anderson, E. 2002. Endosperm Mucilages of Legumes [WWW Document].

Borrelli, F. \& Izzo, A. A. 2000. The plant kingdom as a source of anti-ulcer remedies. Phytotherapy Research: PTR 14(8): 581591.

Busso, N. \& So, A. 2010. Gout. Mechanisms of inflammation in gout. Arthritis Research \& Therapy 12(2): 206.

Castro, R. R., Feitosa, J. P. A., da Cunha, P. L. R., \& da Rocha, F. A. C. 2007. Analgesic activity of a polysaccharide in 
experimental osteoarthritis in rats. Clinical Rheumatology 26(8): 1312-1319.

Chavda, H. V., Patel, M. S., \& Patel, C. N. 2012. Preparation and in vitro evaluation of guar gum based triple-layer matrix tablet of diclofenac sodium. Research in Pharmacentical Sciences 7(1): 57-64.

Chen, L. X. \& Schumacher, H. R. 2008. Gout: An evidence-based review. JCR: Journal of Clinical Rheumatology 14(5S): S55.

Chopra, A., Patil, J., Billempelly, V., Relwani, J., Tandle, H. S., \& WHO-ILAR COPCORD Study. WHO International League of Associations from Rheumatology Community Oriented Program from control of rheumatic diseases 2001. Prevalence of rheumatic diseases in a rural population in western India: a WHO-ILAR COPCORD Study. The Journal of the Association of Physicians of India 49 240-246.

Cronstein, B. N. \& Sunkureddi, P. 2013. Mechanistic aspects of inflammation and clinical management of inflammation in acute gouty arthritis. Journal of Clinical Rheumatology : Practical Reports on Rheumatic \& Musculoskeletal Diseases 19(1): 19-29.

Eggebeen, A. T. 2007. Gout: an update. American Family Physician 76(6): 801-808.

Fjære, E., Aune, U. L., Røen, K., Keenan, A. H., Ma, T., Borkowski, K., Kristensen, D. M., Novotny, G. W., Mandrup-Poulsen, T., Hudson, B. D., Milligan, G., Xi, Y., Newman, J. W., Haj, F. G., Liaset, B., Kristiansen, K., \& Madsen, L. 2014. Indomethacin treatment prevents high fat diet-induced obesity and insulin resistance but not glucose intolerance in C57BL/6J mice. The Journal of Biological Chemistry 289(23): 16032-16045.

Gamal-Eldeen, A. M., Amer, H., \& Helmy, W. A. 2006. Cancer chemopreventive and anti-inflammatory activities of chemically modified guar gum. Chemico-Biological Interactions 161(3): 229-240.

Gryglewski, R. J., Dembínska-Kieć, A., \& Korbut, R. 1978. A possible role of thromboxane A2 (TXA2) and prostacyclin (PGI2) in circulation. Acta Biologica Et Medica Germanica 37(5-6): 715-723.

Hoffmeister, C., Silva, M. A., Rossato, M. F., Trevisan, G., Oliveira, S. M., Guerra, G. P., Silva, C. R., \& Ferreira, J. 2014. Participation of the TRPV1 receptor in the development of acute gout attacks. Rheumatology (Oxford, England) 53(2): 240-249.

Högberg, J., Larson, R. E., Kristoferson, A., \& Orrenius, S. 1974. NADPH-dependent reductase solubilized from microsomes by peroxidation and its activity. Biochemical and Biophysical Research Communications 56(3): 836-842.

Kim, H. A., Seo, Y.-I., \& Song, Y. W. 2014. Four-week effects of allopurinol and febuxostat treatments on blood pressure and serum creatinine level in gouty men. Journal of Korean Medical Science 29(8): 1077-1081.

Kim, H.-Y. 2015. Statistical notes for clinical researchers: post-hoc multiple comparisons. Restorative Dentistry \& Endodontics 40(2): 172-176.

King, E. J., Abul-Fadl, M. A. M., \& Walker, P. G. 1951. KingArmstrong phosphatase estimation by the determination of liberated phosphate*. Journal of Clinical Pathology 4(1): 85-91.

Krotkiewski, M. 1984. Effect of guar gum on body-weight, hunger ratings and metabolism in obese subjects. The British Journal of Nutrition 52(1): 97-105.

Kuo, C.-F., Grainge, M. J., Zhang, W., \& Doherty, M. 2015. Global epidemiology of gout: prevalence, incidence and risk factors. Nature Reviews Rheumatology 11(11): 649.

Lemos Lima, R. de C., Ferrari, F. C., de Souza, M. R., de Sá Pereira, B. M., de Paula, C. A., \& Saúde-Guimarães, D. A. 2015. Effects of extracts of leaves from Sparattosperma leucanthum on hyperuricemia and gouty arthritis. Journal of Ethnopharmacology 161(Supplement C): 194-199.
Li, L., Teng, M., Liu, Y., Qu, Y., Zhang, Y., Lin, F., \& Wang, D. 2017. Anti-gouty arthritis and antihyperuricemia effects of sunflower (Helianthus annuus) head extract in gouty and hyperuricemia animal models. BioMed Research International 2017.

Li, S., Sun, Z., Zhang, Y., Ruan, Y., Chen, Q., Gong, W., Yu, J., Xia, W., He, J. C.-J., Huang, S., Zhang, A., Ding, G., \& Jia, Z. 2017. COX-2/mPGES-1/PGE2 cascade activation mediates uric acid-induced mesangial cell proliferation. Oncotarget 8(6): 10185-10198.

Marklund, S. \& Marklund, G. 1974. Involvement of the superoxide anion radical in the autoxidation of pyrogallol and a convenient assay for superoxide dismutase. European Journal of Biochemistry 47(3): 469-474.

Moilanen, L. J., Hämäläinen, M., Lehtimäki, L., Nieminen, R. M., \& Moilanen, E. 2015. Urate crystal induced inflammation and joint pain are reduced in transient receptor potential ankyrin 1 deficient mice - potential role for transient receptor potential ankyrin 1 in Gout. PLoS ONE 10(2):.

Morris, J. B. 2010. Morphological and reproductive characterization of guar (Cyamopsis tetragonoloba) genetic resources regenerated in Georgia, USA. Genetic Resources and Crop Evolution 57(7): 985-993.

Moteriya, P., Ram, J., Moradiya, R., \& Chanda, S. 2015. In vitro free radical scavenging and antimicrobial activity of Cyamopsis tetragonoloba L. Journal of Pharmacognosy and Phytochemistry 4(2): 102-106

Mudgil, D., Barak, S., \& Khatkar, B. S. 2014. Guar gum: processing, properties and food applications-A review. Journal of Food Science and Technology 51(3): 409-418.

Mukhtar, H. M., Ansari, S. H., Ali, M., Bhat, Z. A., \& Naved, T. 2004. Effect of aqueous extract of Cyamopsis tetragonoloba Linn. beans on blood glucose level in normal and alloxaninduced diabetic rats. Indian Journal of Experimental Biology 42(12): 1212-1215.

Neogi, T., Jansen, T. L. T. A., Dalbeth, N., Fransen, J., Schumacher, H. R., Berendsen, D., Brown, M., Choi, H., Edwards, N. L., Janssens, H. J. E. M., Lioté, F., Naden, R. P., Nuki, G., Ogdie, A., Perez-Ruiz, F., Saag, K., Singh, J. A., Sundy, J. S., Tausche, A. -K., Vaquez-Mellado, J., Yarows, S. A., \& Taylor, W. J. 2015. 2015 Gout classification criteria: an American College of Rheumatology/European League Against Rheumatism collaborative initiative. Annals of the Rheumatic Diseases 74(10): 1789-1798.

Rae, S. A., Davidson, E. M., \& Smith, M. J. 1982. Leukotriene B4, an inflammatory mediator in gout. Lancet (London, England) 2(8308): 1122-1124.

Ragab, G., Elshahaly, M., \& Bardin, T. 2017. Gout: An old disease in new perspective - A review. Journal of Advanced Research 8(5): 495-511.

Rasool, M. \& Varalakshmi, P. 2006. Suppressive effect of Withania somnifera root powder on experimental gouty arthritis: An in vivo and in vitro study. Chemico-Biological Interactions 164(3): 174-180.

Review, T. R. 2012. From Food to Fracking: Guar Gum and International Regulation [WWW Document]. The Regulatory Review. URL https://www.theregreview.org/2012/08/08 /8-narayan-guar-gum/ (accessed 11.28.18).

Robinson, P. C. 2018. Gout - An update of aetiology, genetics, comorbidities and management. Maturitas 118 67-73.

Rotruck, J. T., Pope, A. L., Ganther, H. E., Swanson, A. B., Hafeman, D. G., \& Hoekstra, W. G. 1973. Selenium: biochemical role as a component of glutathione peroxidase. Science (New York, N.Y.) 179(4073): 588-590.

Rymal, E., \& Rizzolo, D. 2014. Gout: A comprehensive review. Journal of the American Academy of PAs 27(9): 26. 
Sabina, E. P., Nagar, S., \& Rasool, M. 2011. A role of piperine on monosodium urate crystal-induced inflammation--an experimental model of gouty arthritis. Inflammation 34(3): 184-192.

Sabina, E. P. \& Rasool, M. 2008. An in vivo and in vitro potential of Indian ayurvedic herbal formulation Triphala on experimental gouty arthritis in mice. Vascular Pharmacology 48(1): 14-20.

Samarghandian, S., Saeed, S., Hadjzadeh, M. -A. -R., Mosa-AlReza, H., Amin Nya, F., Fatemeh, A. N., Davoodi, S., \& Saeideh, D. 2012. Antihyperglycemic and antihyperlipidemic effects of guar gum on streptozotocininduced diabetes in male rats. Pharmacognosy Magazine 8(29): $65-72$.

Schlesinger, N., De Meulemeester, M., Pikhlak, A., Yücel, A.E., Richard, D., Murphy, V., Arulmani, U., Sallstig, P., \& So, A. 2011. Canakinumab relieves symptoms of acute flares and improves health-related quality of life in patients with difficult-to-treat Gouty Arthritis by suppressing inflammation: results of a randomized, dose-ranging study. Arthritis Research \& Therapy 13(2): R53.

Sharma, P., Kaur, A., \& Kaur, S. 2017. Nutritional quality of flours from guar bean (Cyamopsis tetragonoloba) varieties as affected by different processing methods. Journal of Food Science and Technology 54(7): 1866-1872.

Sinha, A. K. 1972. Colorimetric assay of catalase. Analytical Biochemistry 47(2): 389-394.

Sophia Fox, A. J., Bedi, A., \& Rodeo, S. A. 2009. The basic science of articular cartilage: structure, composition, and function. Sports Health 1(6): 461-468.

Trostle, C. 2013. Guar in west Texas. Lubbock: Texas A\&M Agrilife Extension, Texas A\&M University.

Udhaya Lavinya, B., Bardhan, I., \& Evan Prince, S. 2016. Efficacy of CoenzymeQ10 in inhibiting monosodium urate crystalinduced inflammation in rats. European Journal of Pharmacology 791 589-594.

van der Heijde, D. 2011. Erosions versus joint space narrowing in rheumatoid arthritis: what do we know? Annals of the Rheumatic Diseases 70 Suppl 1 i116-118.

Whistler, R. L., \& Hymowitz, T. 1979. Guar: Agronomy, Production, Industrial Use, and Nutrition. Purdue University Press, West Lafayette, Ind. 